\title{
Effect of Ethanol Extract and Ethyl Acetate Fraction of Betel Nut (Areca catechu L.) in Colonic Goblet Cells of Mice (Mus musculus) Given Orally Infective Egg of Trichuris muris
}

\author{
Endy Juli Anto ${ }^{1,2 \star}$, Aznan Lelo ${ }^{3}$, Syafruddin Ilyas $^{4}$, Marline Nainggolan ${ }^{5}$ \\ ${ }^{1}$ Faculty of Medicine, Universitas Sumatera Utara, Indonesia; ${ }^{2}$ Department of Parasitology, Faculty of Medicine, University of \\ Methodist, Indonesia; ${ }^{3}$ Department of Pharmacology, Faculty of Medicine, Universitas Sumatera Utara, Indonesian; ${ }^{4}$ Department \\ of Biology, Faculty of Mathematics and Sciences, Universitas Sumatera Utara, Indonesian; ${ }^{5}$ Department of Pharmacy Biology, \\ Faculty of Pharmacy, Universitas Sumatera Utara, Indonesian
}

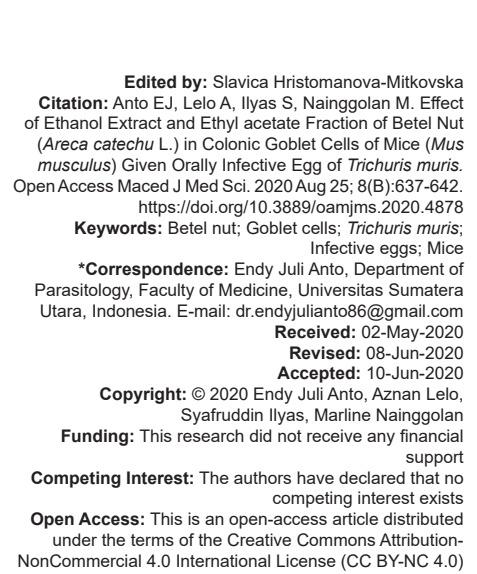

\section{Introduction}

Worm infections, especially infection that is transmitted through worm's egg-contaminated soil (soiltransmitted helminths), are considered as neglected diseases. Intestinal worm infections or intestinal helminthiasis is a chronic condition with no obvious clinical symptoms nor visible short-term effects, yet the attention to this disease is lacking. Trichuris trichiura infection is one of the most difficult conditions to cured compare to otherworm infections. The infection caused by Ascaris lumbricoides and hookworm, for example, could be cured with 1 day medication treatment. T. trichiura infection, on the other side, requires medication for 3 days in a row to show some improvement [1].

\begin{abstract}
BACKGROUND: Trichuris trichiura is a soil-transmitted parasitic worm commonly found in humid, tropical to subtropica Indonesia. This worm infection is more common in developing countries and more in children than adults due to poore child self-hygiene. Worm disease is one of the common society diseases with $60 \%$ of children in Indonesia which are in intestinal crypts of colon and cecum. Goblet cell hyperplasia will occur after exposure to high-dose T. muris (acute/200

AIM: The aim of this research is to determine the effect of ethanol extract and the ethyl acetate fraction of betel nut

METHODS: This study was an experimental study with a post-test only control group design in male mice (Mus musculus) which were given 200 infective eggs of $T$. muris. The study sample consisted of 70 mice divided into seven groups. $100 \mathrm{mg} / \mathrm{kg}$ b.w. and $150 \mathrm{mg} / \mathrm{kg} \mathrm{b.w}$. The independent variable was ethanol extract and ethyl acetate fraction of bete RESULTS: Statistical analysis showed a significant difference of $p<0.05$ in the colonic crypts and cecum. In Group $\mathrm{K}(+)$, there was no increase in the number of goblet cells $(54.2000 \pm 30.54864)$ compared to Group $\mathrm{K}(-)(79.0750$ $\pm 11.79221)$ in the colon. There was an increase in goblet cells in the $150 \mathrm{mg} / \mathrm{kg} \mathrm{b} . \mathrm{w}$. of ethanol extract group $(64.1000 \pm 29.50381)$, the $150 \mathrm{mg} / \mathrm{kg}$ b.w. of ethyl acetate fraction group $(56.2250 \pm 22.11035)$, and the $1 \mathrm{mg} / 20 \mathrm{~g}$ of (68.3750 \pm 11.30956$)$ in the colon. Likewise, there was an increase in the
\end{abstract} CONCLUSION: Ethanol extract of betel nut $150 \mathrm{mg} / \mathrm{kg}$ of weight can effectively increase the number of goblet cells in the colon and caecum. 
the tissue are stimulated by the activation of eosinophil chemotaxis factor (ECF)-A mast cell degranulation (ECF). The body's immune response to the worms will then stimulate the formation of antigens. Antigenpresenting cells (APCs) can stimulate Th0 so that the immune response develops toward Th2.

Immunity arising from the helminthiasis can change the morphology and number of cells, depending on mucosal induction as well as the mechanism of mucus production by goblet cells. Goblet cells are the important elements of the immune response to T. muris. Goblet cells in the intestinal epithelium produce mucus as an immune defense to respond inflammation in the digestive tract. The more inflammatory cells, the more mucus produced by goblet cells as a defense cell.

In the past few years, potential medicinal plants as one of the alternatives to minimize side effects and to treat intestinal infection have been developed. Betel nut of Areca catechu L. ( $A$. catechu L.) has been known as anthelmintic [2]. Betel nut can act as anthelmintic and anti-inflammatory against worm parasitic infections. Betel nuts contain alkaloid compounds (are coline, arecolidine, arecaine, guvacoline, guvacine, and isoguvacine), condensed, and hydrolyzed tannins, flavonoids (flavones), enolic compounds, gallic acid, sap, lignin, evaporated and non-evaporating oils, and salts.

This study discusses the changes in the number of goblet cells in the large intestine of mice (Mus musculus) that are fed with $T$. muris infective eggs treated with ethanol extract as well as with the ethyl acetate fraction of betel nut. The examination of the number of goblet cells is a rare study. This study aims to determine the effect of ethanol extract and ethyl acetate fraction of betel nut seeds on the number of intestinal goblet cells in male mice that were given T. muris infective eggs through oral administration.

\section{Materials and Methods}

\section{Experimental design}

This study is an experimental study with a post-test only control group design, using male mice (M. musculus) fed with $T$. muris infective eggs. The inclusion criteria were as follows: (1) Male mice (M. musculus) age 2 months old, (2) mice are in a healthy/active condition, (3) mice weigh are between 20 and $30 \mathrm{~g}$, and (4) mice were infected with a dose of 200 T. muris infective eggs. The exclusion criterion was male mice that died during the study. Furthermore, the independent variable examined in this study is the dose of ethanol extract (150 mg/kg b.w. and $100 \mathrm{mg} / \mathrm{kg} \mathrm{b.w.)}$ and ethyl acetate fraction $(150 \mathrm{mg} / \mathrm{kg} \mathrm{b.w.} \mathrm{and} 100 \mathrm{mg} / \mathrm{kg}$ b.w.) of betel nut ( $A$. catechu $\mathrm{L}$ ) and albendazole $1 \mathrm{mg} / 20$ $\mathrm{g}$. The dependent variable is the number of goblet cells.

\section{Experimental groups}

The sample of this study consisted of 70 mice which were divided into seven groups, in which each group contained 10 mice. The negative control group was given no treatment other than ad libitum food and drink in their cages as common practice. Meanwhile, the positive control group was given 200 eggs T. muris infective (acute infection). Group P1 was the treatment group administered with ethanol extract of betel nut $100 \mathrm{mg} / \mathrm{kg}$ b.w, Group P2 was administered with ethanol extract of betel nut $150 \mathrm{mg} / \mathrm{kg}$ b.w, Group P3 was administered with ethyl acetate fraction of betel nut 100 mg/kg b.w, Group P4 was administered with ethyl acetate fraction of betel nut $150 \mathrm{mg} / \mathrm{kg} \mathrm{b.w}$, and Group P5 was administered with albendazole $1 \mathrm{mg} / 20 \mathrm{~g}$.

\section{Identification of betel nut samples}

Researchers have identified the sample in the Indonesian Institute of Sciences laboratory.

\section{Preparation of ethanol extract of betel nut}

The sample used was $10 \mathrm{~kg}$ of betel nut taken from the areca nut plantation in the Rantau Prapat area of Medan. The samples were cleaned from dirt and separated from the mesocarp (wet sortation) by washing them with running water until clean. The nuts were dried in an oven with a temperature of $50^{\circ} \mathrm{C}$. The dried nuts were then ground to simplicia powder, sifted, and stored in a clean and tightly closed container. The powder was macerated using $96 \%$ ethanol solvent. A total of $1000 \mathrm{~g}$ of simplicia powder was put into a container and incorporated with 75 parts of $96 \%$ ethanol $(4.2 \mathrm{~L})$. The container was covered protected from light and left for 3 days with occasional stirring. After the following 3 days, the juice was separated from the waste residual.

The residual was then again blended with 75 parts of $96 \%$ ethanol ( $4.5 \mathrm{~L})$, stirred, and cleaned to obtain 100 parts of the whole juice. The container was closed, kept at room temperature, and protected from light for 2 days. The precipitate was then separated thus a liquid extract was obtained. Thereafter, the liquid extract was evaporated using a rotary evaporator at a temperature of $30-40^{\circ} \mathrm{C}$ jnand then concentrated using a freeze dryer at a temperature of $-4^{\circ} \mathrm{C}$ to obtain a dry extract of betel nut.

\section{betel nut \\ Preparation of ethyl acetate fraction of}

The fraction was produced by liquid extraction using ethyl acetate solvent. A total of $10 \mathrm{~g}$ of ethanol extract and $100 \mathrm{ml}$ of distilled water were homogenized, brought into a separating funnel, and allowed to stand for a while. Ethyl acetate fraction $(50 \mathrm{ml})$ was added into 
the tunnel, shaken, allowed to stand until the layer of ethyl acetate fraction formed. Fractionation was carried out until the ethyl acetate layer was pure.

\section{Infective eggs administration}

Mice in each treatment group were orally induced with 200 T. muris infective eggs, except the negative control group, and were left for 30 days. On day $31^{\text {st }}-33^{\text {rd }}$, the positive control group was vacated from any treatment. On day $37^{\text {th }}$, mice were sacrificed.

\section{tannins \\ Identification of alkaloids, flavonoids, and}

\section{Alkaloids}

Reagents used for the identification of alkaloids were Bouchardat's reagent, Dragendorff's reagent, Mayer's reagent, and Wagner's reagent. A sufficient amount of samples was placed into the tube and mixed with each reagent. One different test tube was used for each test. The positive Bouchardart test would be shown through the formation of chocolate deposits while the formation of brick red deposits would be the positive sign of the Dragendorff's test. Mayer's reagent positive test would be shown by the formation of yellowish-white deposits. Meanwhile, positive Wagner's reagent test would be shown by the formation of chocolate deposits.

\section{Flavonoids}

Flavonoid test was carried out using $\mathrm{FeCl}_{3} \mathrm{Mg} /$ $\mathrm{HCl}(p), \mathrm{H}_{2} \mathrm{SO}_{4}(p)$, and $\mathrm{NaOH} 10 \%$ reagents. Each test involved an adequate amount of sample placed in a test tube and mixed with each reagent. A positive $\mathrm{FeCl}_{3}$ test would be shown by the formation of black colloids while positive test $\mathrm{Mg} / \mathrm{HCl}$ would be shown by the pink solution. The $\mathrm{H}_{2} \mathrm{SO}_{4}$ test would show positive results with the formation of a yellowish-orange solution. The $\mathrm{NaOH} 10 \%$ test would show the positive result with the formation of a blue-violet solution.

\section{Tannins}

The tannins test was carried out by dissolving the sample extract into methanol until the sample was completely submerged. Then, add 2-3 drops of $1 \%$ $\mathrm{FeCl}_{3}$ solution. Positive results are indicated by the formation of bluish-black or green.

\section{Analysis of the number of intestinal goblet} cells

The sample used in this study was colon and cecum. Then, each part is divided. Each part of the colon and cecum is cut $1 \mathrm{~cm}$ long, then washed using $5 \%$ formaldehyde so that the remaining dirt is removed and given a fixative solution of $10 \%$ formaldehyde. After that, histopathological preparations are made and stained with hematoxylin and eosin. The calculated parameter is the number of goblet cells per 1000 absorptive cells in the crypto colon and cecum [3].

\section{Hematoxylin-Eosin (HE) Staining}

The exploration of the large intestine was carried out, especially to the proximal colon and cecum. The number of goblet cells was calculated through the examination method of HE staining (Figure 1). The staining procedure used in this research followed a basic protocol of dewaxing, dehydration, hematoxylin, differentiation, bluing, eosin, dehydration, clearing, and coverslipping [4].

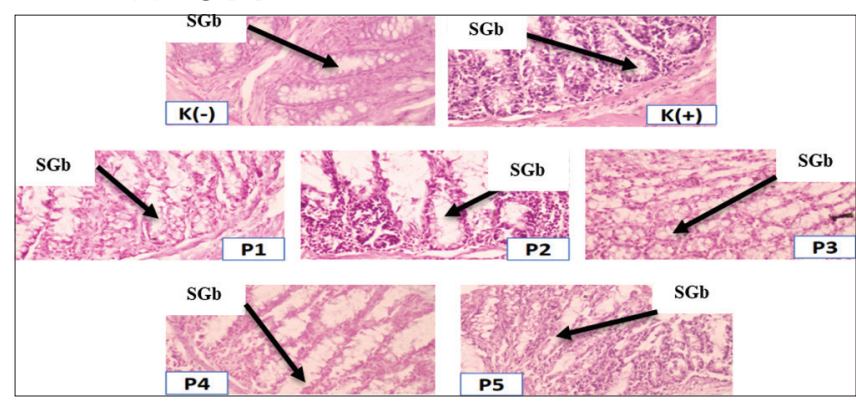

Figure 1: Histopathology of the large intestine (colon proximal) in the male mice on the $37^{\text {th }}$ day after oral administration of 200 infective eggs of Trichuris muris. Samples were taken by longitudinal cuts

\section{Results}

\section{Analysis of betel nuts identification}

The result shows that the betel nut used is identified as the seed of $A$. catechu L., species member of the family Arecaceae (Table 1).

Table 1: Identification or determination of betel nut (Areca catechu L.)

\begin{tabular}{lll}
\hline Name & Species & Family \\
\hline Betel nut & Areca catechu $L$. & Arecaceae \\
\hline
\end{tabular}

Identification of alkaloids, flavonoids, and tannins in ethanol extract and ethyl acetate fraction of betel nut is presented in Tables 2-4.

Table 2: Identification of alkaloids

\begin{tabular}{lllll}
\hline Sample & Reagent & & & \\
\cline { 2 - 5 } & $\begin{array}{l}\text { Bouchardat's } \\
\text { reagent }\end{array}$ & $\begin{array}{l}\text { Dragendorff's } \\
\text { reagent }\end{array}$ & $\begin{array}{l}\text { Mayer's } \\
\text { reagent }\end{array}$ & $\begin{array}{l}\text { Wagner's } \\
\text { reagent }\end{array}$ \\
\hline Ethanol extract of betel nut & + & +++ & +++ & +++ \\
Ethyl acetate fraction of betel nut & + & ++ & +++ & ++ \\
\hline
\end{tabular}

The qualitative identification results show that the ethanol extract of betel nut contains more alkaloids

Table 3: Identification of flavonoids

\begin{tabular}{lllll}
\hline Sample & Reagent & & & \\
\cline { 2 - 5 } & $\mathrm{FeCl}_{3} 5 \%$ & $\mathrm{NaOH} 10 \%$ & $\mathrm{H}_{2} \mathrm{SO}_{4}$ & $\mathrm{Mg}+\mathrm{HCl}$ \\
\hline Ethanol extract of betel nut & +++ & +++ & ++ & +++ \\
Ethyl acetate fraction of betel nut & +++ & ++ & + & + \\
\hline
\end{tabular}


Table 4: Identification of tannins

\begin{tabular}{ll}
\hline Sample & Reagent \\
\cline { 2 - 2 } & $\mathrm{FeCl}_{3} 1 \%$ \\
\hline Ethanol extract of betel nut & +++ \\
Ethyl acetate fraction of betel nut & +++ \\
\hline
\end{tabular}

than the ethyl acetate fraction, both in Dragendorff's reagent and Wagner's reagent (Table 2 ).

The results show that the flavonoids contained in ethanol extract of betel nut (in all reagents used) are greater than in the ethyl acetate fraction, either the one reacted with $\mathrm{FeCl}_{3} 5 \%, \mathrm{NaOH} 10 \%, \mathrm{H}_{2} \mathrm{SO}_{4}$, or $\mathrm{Mg}+\mathrm{HCl}$ reagents (Table 3 ).

Based on the identification results in Table 4, the ethanol extract of betel nuts has the same tannins content with the ethyl acetate fraction of betel nuts. The results of the analysis of the number of intestinal goblet cells are presented in Table 5.

Table 5: Number of the goblet cells in the intestinal tunica mucosa of male mice on the $37^{\text {th }}$ day after the oral administration of infective eggs of Trichuris muris

\begin{tabular}{|c|c|c|c|}
\hline \multicolumn{4}{|c|}{ Structure of intestinal tunica mucosa $(\mu \mathrm{m})$} \\
\hline Number of goblet cell in & Group & Mean \pm SD & $\mathrm{p}$ \\
\hline \multirow[t]{6}{*}{ Crypts of colon } & $\mathrm{K}(-)$ & $79.0750 \pm 11.79221$ & $0.000^{*}$ \\
\hline & $\mathrm{P} 1$ & $27.6750 \pm 10.70374$ & \\
\hline & P2 & $64.1000 \pm 29.50381$ & \\
\hline & P3 & $53.6250 \pm 18.61759$ & \\
\hline & P4 & $56.2250 \pm 22.11035$ & \\
\hline & P5 & $68.3750 \pm 11.30956$ & \\
\hline \multirow[t]{7}{*}{ Cecum } & $\mathrm{K}(-)$ & $10.6000 \pm 6.46808$ & $0.000^{*}$ \\
\hline & $\mathrm{K}(+)$ & $9.5000 \pm 2.06492$ & \\
\hline & P1 & $13.5250 \pm 6.97461$ & \\
\hline & P2 & $29.0250 \pm 7.65257$ & \\
\hline & P3 & $26.6000 \pm 4.88791$ & \\
\hline & P4 & $11.4000 \pm 4.21670$ & \\
\hline & P5 & $11.1750 \pm 4.50779$ & \\
\hline
\end{tabular}

${ }^{*}$ Mann-Whitney

Goblet cells in the colon and cecum showed significant differences in the number of goblet cells $(p<0.05)$.

\section{Discussion}

Helminthiasis is a multicellular and complex parasite. It has a long life span and cannot be swallowed by phagocytes so that the host response to helminth infections is usually more complex and stronger [5], [6]. The reaction of the body to fight helminthiasis is characterized by an increase of $\mathrm{lgE}$, tissue eosinophils, mastocyte, and CD4+ cells that produce $T$ helper 2 (Th2) cells [7]. Worm infection will stimulate APC which will stimulate Th0 so that the immune response develops toward Th2. Recent immune-epidemiological data indicate that the immune response mediated by Th2 cells take part in limiting this worm population [8].

Treatment using medicinal plants is one of the alternatives chosen to minimize the side effects due to the provision of synthetic drugs. Common side effects of anthelmintic medication include stomach pain, diarrhea, and digestive disorders. It may also cause nausea and vomiting for some people. The medicinal plants have been known to have anti-worm or anthelminthic properties and used until today. From several studies that have been carried out, betel nut (A. catechu L.) is one plant that has anthelmintic properties.

Betel nuts contain alkaloids, such as arecoline $\left(\mathrm{C}_{8} \mathrm{H}_{13} \mathrm{NO}_{2}\right)$, arecolidine, arecain, guvacoline, guvacine and isoguvacine [9]. The dominant type of alkaloid found in betel nut which is likely to have an anthelmintic effect is arecoline [10]. Arecoline is toxic to several types of worms and causes temporary paralysis [11]. According to Nonaka et al. [12] areca nut seeds contain proanthocyanidin, which is a condensed tannin included in the flavonoid class.

Tannins of the ethanol extract of betel nuts have the anthelmintic ability that works by inhibiting the enzymes as well as damaging the membrane [13]. Inhibition of the work of enzymes can cause the process of digestion metabolism of the worm disrupted. The worms would be lack in nutrients and eventually die due to lack of energy. The ethanol extract of betel nut contains a complex metabolite compound compared to the extract of the betel nut ethyl acetate from the results of the phytochemical ring. The ethyl acetate fraction is an advanced process of ethanol extract.

Worm immunity can cause morphological changes as does the number of cells that depend on mucosal induction including the mechanism of mucus production by goblet cells [14]. Goblet cells are an important element of the immune response to T. muris worms [15]. The function of goblet cells in the intestinal epithelium produces mucus as an immune defense from the digestive tract that occurs due to inflammation. The more inflammatory cells, the more mucus produced by goblet cells as a cell defense [16].

Phytochemical screening results of the ethanol extract of betel nut that the flavonoids contained in it have a role to inhibit many oxidation reactions that arise due to damage to $T$. muris worms, both enzymatically and non-enzymatically through the role of increasing goblet cells in the worm removal process. This activity can disrupt metabolism and homeostasis in the worm's body so that the worm will die [17], [18].

This study shows that there is a significant difference in the number of goblet cells in the colon and cecum between each group of mice $(p<0.05)$ (Table 5$)$. However, the $\mathrm{K}(+)$ group showed no increase in the number of goblet cells $(54.2000 \pm 30.54864)$ compared to the $\mathrm{K}(-)$ group $(79.0750 \pm 11.79221)$ and other groups (Table 5). It indicates that mice have an immune system that is susceptible to helminth infections and betel nut extract may help increase goblet cells in the worm expulsion process.

The administration of $T$. muris infective eggs can significantly increase the number of goblet cells in the intestinal crypts of colon and cecum. It has been 
informed that goblet cell hyperplasia will occur after exposure to high-dose T. muris (acute/200 infective eggs) in resistant mice [15].

Goblet cells are the main producer of mucus, which form the important innate defense element in the gastrointestinal tract. Goblet cells and their products are important elements of the host immune response to T. muris and appear to be crucial for effective cleansing of parasites from the intestine [15]. Goblet cells secrete resistin-like molecules $\beta$ (RELM- $\beta$ ). RELM- $\beta$ is indispensable for spontaneous worm expulsion [19]. In this study, there were mice that were resistant and susceptible, which mean that some mice have a role in the exclusion of worms in the "weep and sweep" response.

Goblet cells are the main producers of mucin and form an important innate defense element in the gastrointestinal tract. Goblet cells and their products are important elements of the host immune response to $T$. muris and appear to be indispensable for effective cleansing of parasites from the intestine [15]. Goblet cells secrete RELM- $\beta$. RELM- $\beta$ is indispensable for spontaneous worm expulsion [19].

Epithelial cell replacement is the main mechanism of $T$. muris expulsion. This model of epithelial cell replacement is called an epithelial escalator. Epithelial cells move from the base of the crypts (proliferation zone) to the top of the villi (release zone). As a result, worms attached to the epithelial layer are directed to move toward the lumen where the parasite and epithelium are released. The difference in epithelial cell replacement between susceptible and resistant mice is due to differences in the immune response and its cytokine profile. Th1 and Th2 responses are, respectively, associated with a decrease and increase in regulation of epithelial turnover speed [15]. Phytochemical screening of the ethanol extract of betel nut contains flavonoids and alkaloids which are more in terms of qualitative inspection compared to ethyl acetate fraction.

The results of the examination of the number of goblet cells (Table 5 ) show the effect of a higher number of goblet cells on ethanol extract $150 \mathrm{mg} / \mathrm{kg}$ b.w. (P2) compared to the ethyl acetate fraction $150 \mathrm{mg} / \mathrm{kg} \mathrm{b.w}$. likewise with the ethanol extract dose of $100 \mathrm{mg} / \mathrm{kg}$ b.w. and ethyl acetate fraction of $100 \mathrm{mg} / \mathrm{kg}$ b.w. This study shows that the treatment of ethanol extract of betel nut $150 \mathrm{mg} / \mathrm{kg}$ b.w can increase the number of goblet cells in worm expulsion compared to the other dose $100 \mathrm{mg} / \mathrm{kg}$ b.w, the ethyl acetate fraction $100 \mathrm{mg} / \mathrm{kg}$ b.w and $150 \mathrm{mg} / \mathrm{kg}$ b.w, as well as compared to albendazole $1 \mathrm{mg} / 20 \mathrm{~g}$. The difference in the number of goblet cells (Table 5) in the colon organ shows significant results between the negative control groups and positive controls, P1, P2, P3, P4, and P5. Likewise, the cecum organs are examined.

\section{Acknowledgment}

The research team thanks Prof. Colby Zaphvia (Colby.zaph@monash.edu), from the Department of Biochemistry and Molecular Biology, Monash Biomedicine Discovery Institute, Monash University, for the help in the provision of T. muris infective eggs.

\section{References}

1. Hotez PJ, Molyneux DH, Fenwick A, Kumaresan J, Sachs SE, Sachs JD, et al. Control of neglected tropical diseases. N Engl J Med. 2007;357(10):1018-27.

PMid:17804846

2. Srichaikul B, Samappito S, Bakker G, Seubsoh W, Boonsong K Comparative double blind trial in antihelmintic efficacy between mebendazole and Areca catechu L. Res J Med Sci. 2012;6(3):124-8.

3. Miller HR, Nawa Y. Nippostrongylus brasiliensis: Intestinal goblet-cell response in adoptively immunized rats. J Exp Parasitol. 1979;47(1):81-90.

PMid:421768

4. Ilyas S, Nadapdap TP. Histokimia dan Imunohistokimia Indonesia: Medan USU Press; 2017

5. MacDonald AS, Araujo MI, Pearce EJ. Immunology of parasitic helminth infections. Infect Immun. 2002;70(2):427-33. PMid:11796567

6. Zakeri A, Hansen EP, Andersen SD, Williams AR, Nejsum P. Immunomodulation by helminths: Intracellular pathways and extracellular vesicles. Front Immunol. 2018;9:2349. PMid:30369927

7. Sitcharungsi R, Sirivichayakul C. Allergic diseases and helminth infections. Pathog Glob Health. 2013;107(3):110-5 PMid:23683364

8. Bradley JE, Jackson JA. Immunity, immunoregulation and the ecology of trichuriasis and ascariasis. Parasite Immunol. 2004;26(11-12):429-41. PMid:15771679

9. Wang CK, Lee WH. Separation, characteristics, and biological activities of phenolics in Areca fruit. J Agric Food Chem. 1996;44:2014-9

10. Amudhan MS, Begum VH, Hebbar KB. Areview on phytochemical and pharmacological potential of Areca catechu L. Seed. Int J Pharm Sci Res. 2012;3(11):4151-7.

11. Sharma S, Anand N. Chapter 3-natural product. Pharmacochem Libr. 1997;25:71-123.

12. Nonaka GI, Hsu FL, Nishioka I. Structures of dimeric, trimeric and tetrameric procyanidins from Areca catechu L. J Chem Soc Chem Commun. 1981;15:781-3

13. Shahidi F, Naczk M. Phenolic compounds in cereals and legumes. In: Food Phenolics: Sources, Chemistry, Effects, Applications. Lancaster, PA: Technomic Inc.; 1995. p. 13-8.

14. Turner JE, Stockinger B, Helmby H. IL-22 mediates goblet cell hyperplasia and worm expulsion in intestinal helminth infection. PLoS Pathog. 2013;9(10):e1003698.

PMid:24130494

15. Klementowicz JE, Travis MA, Grencis RK. Trichuris 
muris: A model of gastrointestinal parasite infection. Semin Immunopathol. 2012;34(6):815-28.

\section{PMid:23053395}

16. Erickson NA, Nystrom EL, Mundhenk L, Arike L, Glauben R, Heimesaat MM, et al. The goblet cell protein clca1 (mClca3 or Gob-5) is not required for intestinal mucus synthesis, structure and barrier function in naive or DSS-challenged mice. PLoS One. 2015;10(7):e0131991. PMid:26162072

17. Saxena M, Saxena J, Nema R, Singh D, GuptaA. Phytochemistry of medicinal plants. J Pharmacogn Phytochem. 2013;1:168-82.

18. Poolperm S, Jiraungkoorskul W. An update review on the anthelmintic activity of bitter gourd, Momordica charantia. Pharmacogn Rev. 2017;11(21):31-4.

PMid:28503051

19. Herbert DB, Yang JQ, Hogan SP, Groschwitz K, Khodoun M, Munitz A, et al. Intestinal epithelial cell secretion of RELM-beta protects against gastrointestinal worm infection. J Exp Med. 2009;206(13):2947-57.

PMid:19995957 